\title{
THE THACKERAYS AND MEDICINE
}

\author{
by
}

\section{ARTHUR ROOK}

FOR ABOUT a century the Thackeray family was prominent in the affairs of both town and university at Cambridge. From 1766 to 1852 Thomas Thackeray and his son Frederic were successively members of the medical staff of Addenbrooke's Hospital and both made important contributions to the development of the hospital and of medical practice in Cambridge. Joseph Thackeray played an equally important role in the development of the Bedford General Hospital. Other members of the family practised successfully in Windsor, in Chester and in India.

THE THACKERAY FAMILY (Melville, 1910; Pryme and Bayne, 1879)

The Thackwra family were tenants of the Abbot of St. Mary of Fountains, Yorkshire in the fourteenth century. They continued as unambitious small landowners and farmers until the death of a childless Thomas Thackeray in 1804. (The modern spelling first appeared in 1618.) Meanwhile two members of the family had sought their fortunes in the South. In 1682 Elias Thackeray (d. 1737) was admitted to Christ's College Cambridge as a sizar. He took his B.A. in 1686 and his M.A. (from Jesus College) in 1709. He was ordained in 1712, when he returned to Yorkshire as Rector of Hawkswell. He is believed to have been responsible for persuading his brother to send his son Thomas (1693-1760), first to Eton and then to King's College, Cambridge. From this Thomas Thackeray, identified in the family histories as the Archdeacon, are descended William Makepeace Thackeray the novelist and all the medical Thackerays.

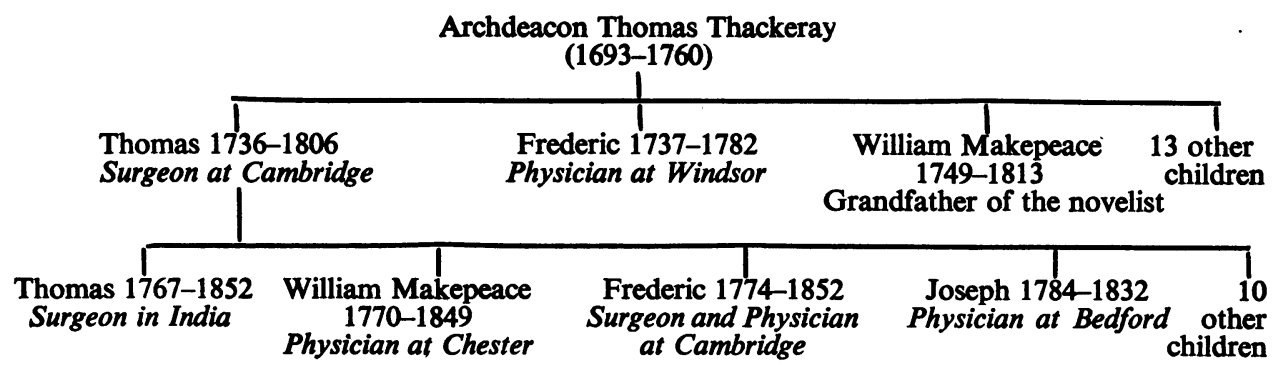

The Archdeacon was born in 1693. From Eton he entered King's College as a scholar in 1711. In due course he proceeded B.A. and M.A. and was ordained. After some years as an assistant master at Eton he became Rector of Haydon and of Chishall Parva and he continued to hold these benefices until his death. In 1743 he was an unsuccessful candidate for the Provostship of King's College. Three years later he was appointed headmaster of Harrow. In 1729 he had married Anne Woodward; between 1730 and 1749 she was mother of sixteen children. Their third son Elias (b. 1732) became Vice-Provost of King's College. Their sixth child was Thomas 


\section{The Thackerays and Medicine}

(b. 1736), surgeon to Addenbrooke's Hospital and father of Thomas, who practised medicine in India, another William Makepeace who practised medicine in Denbigh and later in Chester, Frederic, surgeon and later physician to Addenbrooke's Hospital, Martin, who became Vice-Provost of King's College, and Joseph, Physician to Bedford Infirmary. The seventh child of the Archdeacon was Frederic (b. 1737) who practised medicine at Windsor. Their youngest child was William Makepeace (b. 1749), grandfather of William Makepeace (1811-1863), the author.

\section{THOMAS THACKERAY (1736-1806)}

Thomas Thackeray entered Eton, where his father was an assistant master, on his sixth birthday. When he left school his elder brother Elias, who was a Fellow of King's College, arranged for him to be apprenticed as a private pupil to Richard Hayles, a successful surgeon at Cambridge. His fellow pupil was Thomas Geary Collum (1741-1831), who later succeeded to a baronetcy and became Bath King-atarms; he practised as a surgeon at Bury St. Edmunds.

After completing his apprenticeship Thomas settled in practice in Cambridge. There is no evidence that he attended any hospital in London or elsewhere. He was never a member of the University but he may well have attended lectures in anatomy, chemistry and materia medica for many local practitioners did so. He never became a Member of the Company of Surgeons. He appears rapidly to have acquired a large practice. Fortune favoured him; in 1765 a barrister patient, Jacob Butler, left him the large house in St. Andrew's Street in which he lived for the rest of his life.

On 22 September 1766 he was elected surgeon to Addenbrooke's Hospital, which admitted its first patients the following month. His senior surgical colleagues were his former master, Richard Hayles, and Allen Hopkins. The Hospital Minute Books record Thomas's regular attendance at Weekly Boards, but tell nothing of his surgical activities. He and his colleagues were in 1780 and in 1791 each presented with silver plate to the value of twenty guineas in appreciation of their services. In September 1796 Thomas resigned in favour of his son, and was requested to continue as Consulting Surgeon.

According to his daughter, Thomas was a close friend of Robert Glynn (1719-1800) Physician to Addenbrooke's Hospital and Fellow of King's College. Glynn certainly called him out frequently in consultation (Rook, 1969). Thomas Gray was one of their patients; on $10 \mathrm{July,} 1764$ he wrote to Wharton, 'the fault lay in deferring matters too long and upon inspection they found no reason to apprehend a fistula, but the piles only in an extreme degree, that threatened mortification. Nine or 10 strokes of the lancet and the application of a caustic with fomentations innumerable I suffered manfully: indeed the pain in idea is much greater than in reality'. And later in the same year he wrote to Mary Antrobus '... I am no friend to Surgeons and in this case particularly (as the seat of her malady is so near a very tender part, that is not to be trifled with) I should by no means suffer them to proceed to any operation without the professor's* inspection and advice. If he declares it necessary let her not be frighted at the sight of steel, for I can tell her upon some experience, that one half hour

\footnotetext{
* The Regius Professor of Physic, Russell Plumptre (1709-1793)
} 


\section{Arthur Rook}

of the pain she undergoes from her illness is more than all she will suffer from $\mathrm{Mr}$ Thackeray's hand' (Toynbee and Whibley, 1935).

The Poor Relief accounts of several parishes record many payments made to Thomas Thackeray. His fee for a Parish visit appears to have been 10s. 6d., for this is the smallest sum ever paid him. In the accounts of St. Edward's Parish there are very frequent payments to the Apothecary, Macro, and payments to Thackeray only once or twice each year. In 1773 he was paid 'for Ann Brown, £5. 5. 0.'. In 1779 'for tending Wettenhall 10.6' and in 1784 'for searching the body of Gaylor, $£ 1.1$. 0.'. These and other records suggest that at this period the parishes called in a surgeon only for the more serious conditions.

Of Thackeray's earnings in private practice less is known. On one occasion (Pryme and Bayne, 1879) Glynn and Thackeray attended a Mr. Panton of Newmarket. Their fees were $£ 80$ and $£ 50$ respectively.

His daughter Jane describes him as a tall handsome man, with a pleasing manner. 'My father would often quote to his children at suitable opportunities, maxims and proverbs for their guidance.' A former patient remembered that 'if he was consulted by a student for any bodily infirmity he never missed the opportunity of improving the mind too!'

In July 1763 he married Lydia, the daughter of Richard Which of Cambridge; she bore him fifteen children. He died on 27 November 1806. A memorial tablet was erected in St. Andrew's Church.

\section{FREDERIC THACKERAY}

Frederic, the fifth son of Thomas and Lydia, was born in Cambridge on 11 February 1774 . He was at school at Rugby and was then apprenticed to his father. In a letter written many years later he mentioned that he had worked as a pupil at Addenbrooke's Hospital. His elder brother Thomas (b. 1767) was a house pupil of John Hunter and a friend of Astley Cooper. Frederic may also have worked in London, for his obituarist in the Cambridge Chronicle claims that he was a friend and pupil of Astley Cooper. Frederic, with his brothers Thomas and William (b. 1770), visited Paris with Cooper in 1792. They arrived in June and attended the lectures of Desault and Chopart. The Revolution reached its most bloody phase whilst they were in Paris. They passed through the mob escorting Louis XVI to the Temple, but were able to return to England in September (Cooper, 1843). There was so much anxiety about their safety that the bells of St. Andrew's Church rang a merry peal when they arrived in Cambridge. After completing his apprenticeship Frederic entered practice as a surgeon at Cambridge.

On 12 September 1796 a letter from Thomas Thackeray was read to the Weekly Meeting of the Governors of Addenbrooke's Hospital. 'Gentlemen, having a son who has been regularly brought up to the Profession and will be happy to succeed me as one of the Surgeons to Addenbrooke's Hospital, I give notice of my intention to resign and if he should be the object of your choice I flatter myself he will pay the same attention to the patients as I have ever done.' On 3 October Frederic Thackeray was elected surgeon. Although he continued as surgeon until 1817 he began to consider becoming a physician as early as 1800 and in May of that year he was first entered as 

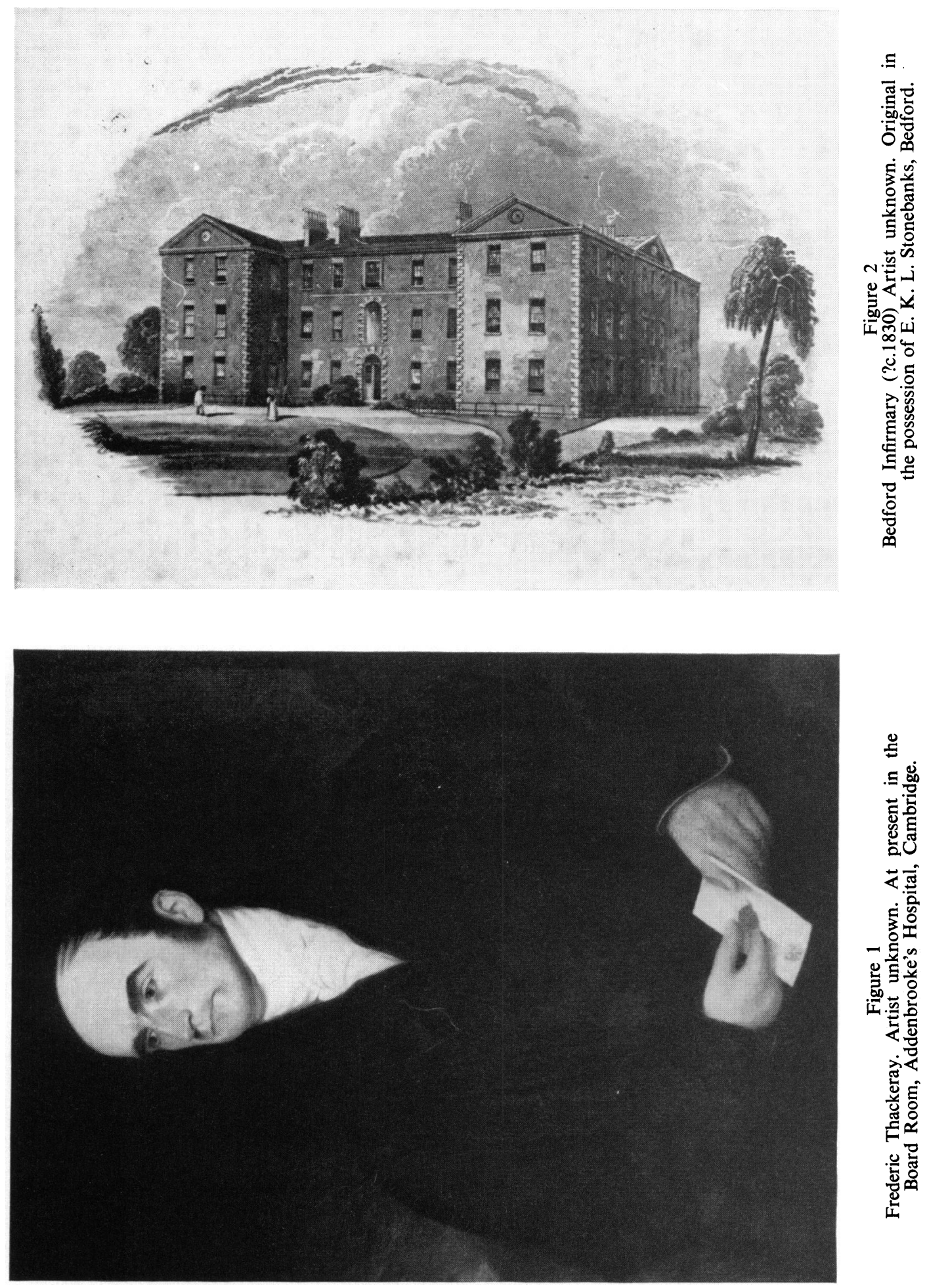

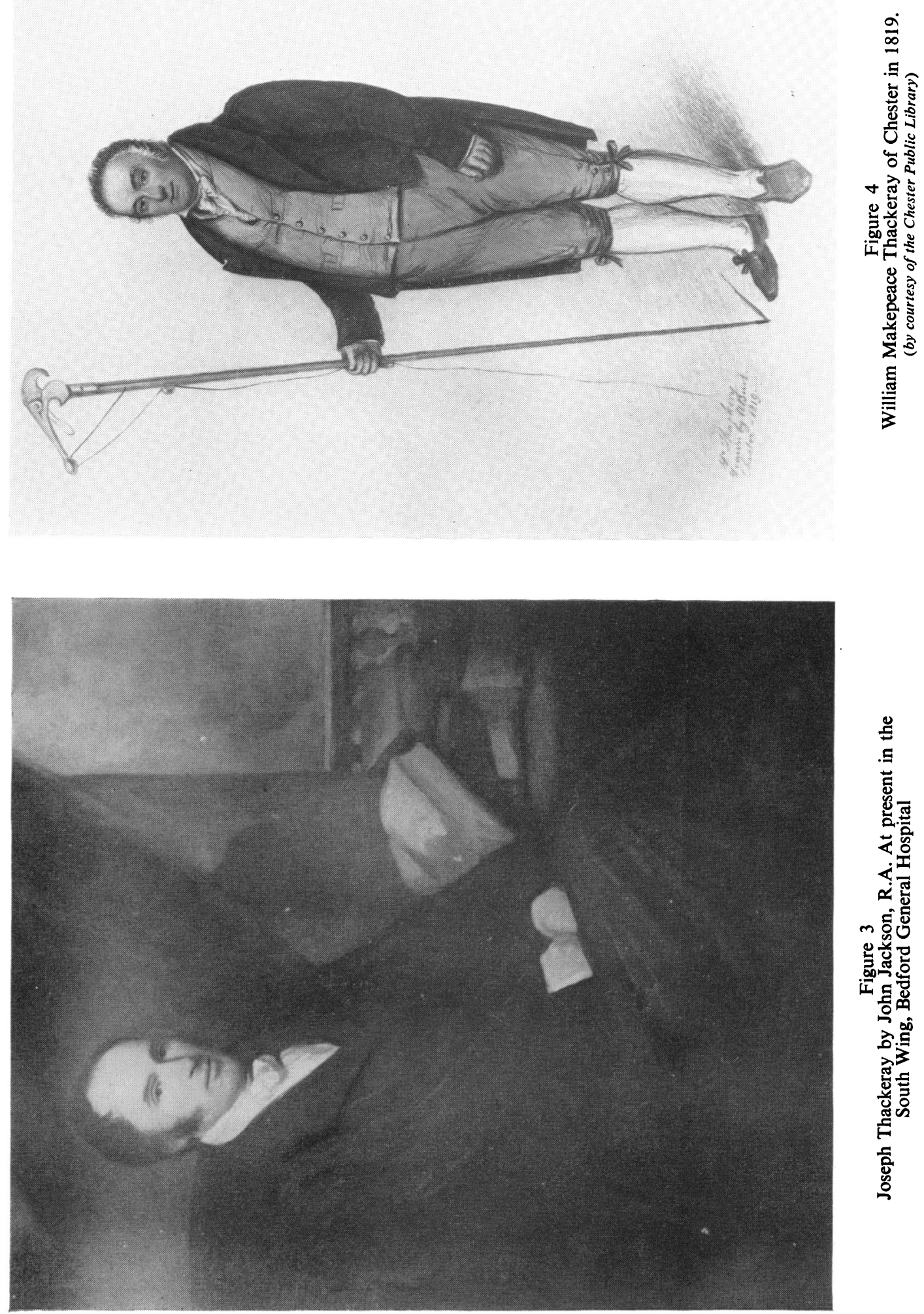
a Fellow Commoner at Emmanuel College. In 1804 however Sir Isaac Pennington the Regius Professor of Physic unexpectedly refused to allow him to keep an act for a first degree in medicine, on the grounds that the Elizabethan statutes excluded him because he was in professional practice. The controversy which followed this refusal aroused great interest at the time (Winstanley, 1955). The Vice-Chancellor Dr. Davy, who had remained in practice as a physician after his election as Master of Caius College in 1803, called a meeting of the Heads which opposed Pennington's interpretation of the Statute. There was much sympathy for Thackeray and much criticism of the Heads. In 1815 they rescinded the unwelcome interpretation and in the same year Thackeray was readmitted a Fellow Commoner of Emmanuel; he took his M.B. in 1815, the M.L. in 1817 and proceeded M.D. in 1820.

On 5 May the following letter from Thackeray was read to the Weekly Meeting at Addenbrooke's Hospital. 'Gentlemen, The University having granted me a Licence to practise as a Physn. I beg leave to resign the office of Surgn. to your benevolent Institution. Connected with the Hospital for so many years I cannot relinquish the important situation in which your confidence placed me without considerable regret; and tho' I shall cease to be one of your Surgns, I shall ever feel deeply interested in the welfare of your Establishment and shd. a vacancy occur in its Medical Department it will always be an object of my ambition to serve as one of your Physicians.' During the next ten years Thackeray, who as a subscriber remained a Governor, was active in hospital affairs. He was elected Physician in 1827 when the next vacancy occurred on the retirement of Thomas Ingle.* In 1843 he had submitted his resignation under a recent regulation that medical staff should resign after twelve years. This regulation had been introduced as part of a scheme to remove from the staff the older surgeons to make room for younger men such as George Murray Humphry who were keen and competent to develop clinical teaching (Rook, 1970). 'Dr Haviland proposed and Mr Mortlock seconded and it was unanimously resolved that the Board duly appreciating the motives which have led Dr Thackeray and Dr Bond $\dagger$ to tender their resignations, at the same time feeling that the loss of their valuable services would be very injurious to the interests of the Charity, Request that these Gentlemen would withdraw their resignations and consent to continue to hold their Offices the duties of which they have so admirably performed'. Thackeray agreed to resume his duties and he finally resigned on 10 March 1845, when he was appointed consulting physician.

Thackeray's services to the hospital over half a century had been considerable. He was assiduous in his attendance at Weekly Meetings and served on many subcommittees, often as chairman. In 1844 he presented the hospital with the London Medical Gazette and a number of books. He wrote 'I have always thought that it would be a great benefit to our Hospital if there was attached to it a medical library not only for the use of the students but as a means of reference to the medical officers. With this feeling I beg to offer to your institution a few books as a foundation and should you think it as advantageous as I do I shall be able to make a considerable addition to it and $I$ hope that the neighbouring surgeons may be permitted to partake of the advan-

* Thomas Ingle (1765-1838) M.D. Fellow of Peterhouse; elected physician in 1793.

† Henry Hayles Bond (1801-1883) M.D., F.R.C.P. Regius Professor of Physic 1851-72. 


\section{Arthur Rook}

tages of such a library if it ever assumes a form to deserve the name, and from the liberality of the Public I have no doubt on the subject'. The governors set up a subcommittee under the chairmanship of Lord Godolphin, which recommended that a library be established under the care of the House Apothecary. Hospital funds could be used for shelves but not for the purchase of books.

Thackeray had earlier shown his interest in improving library facilities. In 1832 he had been a founder member of the Cambridge Medical Book Club, which survived until 1865.

Of Thackeray's medical activities at the hospital the minutes have nothing to record. He certainly built up a very large practice. According to his sister (Pryme and Bayne, 1879) he was well known far beyond Cambridge. She quotes from a letter from Edward Jenner to Sir Charles Morgan in which he refers to Frederic as "his able and excellent friend and one of those enlightened men who will be sure to welcome vaccination and exchange lances with its opponents'. In 1802, together with his fellow surgeons at Addenbrooke's Hospital, he offered 'to inoculate with vaccine matter such persons as might be referred for that purpose' (Minute Books 1802). In 1808 he had occasion to exchange lances with Sir Isaac Pennington who had publicly expressed his doubts about the efficacy of vaccination. Thackeray wrote to the editor of the Cambridge Chronicle:

SIR,

In your paper of last week, Sir Isaac Pennington has brought the subject of vaccination in this place again under discussion, and has stated that he has laid before the College of Physicians twenty-five cases of its failure. If the Professor's opinion was well founded, he would certainly have been culpable in concealing it; but if not, he is deeply responsible for the evil it will occasion. The authority of his name may shake the confidence of many, who, for years past, have considered their children as safe from all danger of infection; and it will tend to check the future progress of a system, which every friend of humanity must at least wish to be successful. The Report* of the Jennerian Society, I thought, had satisfied the most rational part of the community; and I saw with pleasure the inhabitants of our villages submit to vaccination, under a conviction of its security. Their confidence, I trust, is not misplaced, and I feel myself justified from the attention I have paid to this very important subject, in calling upon the public, at least to suspend their judgment till the evidence on which the Professor's assertions are founded is made known.

It is impossible to know or even guess all the cases which compose the document sent to the College of Physicians, but having reason to think that some of the sixteen examined by the Jennerian Society form a part, I must remind the public, that its report declares, 'it did not appear that a single case of the small-pox occurred there, after regular and complete vaccination'; that in several of the reputed failures 'there was only a festering of the arms', and that the 'chicken-pox was mistaken for the small-pox'. Such was the opinion of many other medical men; and I appeal to many of your readers, whether they are not acquainted with cases which Sir I. Pennington pronounced to be small-pox, though the same eruption had attacked three children in the same family, two of whom only had been vaccinated, and the third had had the small-pox.

It is also well known, that several children have been inoculated for the small-pox after vaccination, and because in some of these the arms festered, Sir I. P. declared them to have the small-pox, tho' no eruption appeared. These cases were seen by other medical men, who thought very differently; and I will venture to say, that if any number of persons who had already undergone the small-pox, were re-inoculated for that disorder, the arms of a large proportion of them would fester, and a slight fever would follow; this not unfrequently happens, when the re-inoculation is occasioned by accidental contact, and many a parent has experienced it, who has nursed her child under this afflicting malady.

I should long since have laid before the public some remarks on the supposed failures in this

*See the Chronicle of Sept. 3. 


\section{The Thackerays and Medicine}

place, had I imagined a belief in them existed in the minds of any, except a few prejudiced persons, who opposed the very introduction of vaccination, before its failures were suspected, and every known fact was favourable; and until Sir I. Pennington condescends to lay the particulars of his statement before your readers, he must not expect his bare assertion will influence the judgment of cool and dispassionate enquirers, nor will he easily persuade them, that he only is in the right on this subject, and that the College of Physicians and most scientific men at home and abroad are in an error.

Cambridge, Nov. 3, 1808.

Yours, FREDERIC THACKERAY.

A surgeon in a small country town was in effect a general practitioner. The Country Register of Houses for the Reception of 'Lunatics' (1798-1812) (Hunter et al., 1956) records Thackeray's referral of patients to Dr. Thomas Arnold of Leicester and to Dr. S. M. Cox of Fishponds, Bristol. This register suggests (Hunter 1968) that Thackeray to a greater extent than his colleagues acted as a local psychiatric practitioner in Cambridge. In his practice Thackeray showed his father's fondness for improving maxims; his favourite was 'walk upright and live uprightly'. He was strongly opposed to the current abuse of calomel and brandy in therapeutics. Two days a week he gave free advice to the poor at his house in St. Andrew's Street, to the town poor on Monday morning and to the country folk on Saturday, market day. In 1833 the news of a serious and mysterious outbreak of cholera in Ely reached Cambridge on a Sunday morning. Thackeray, Haviland and some local surgeons set off at once for Ely and spent the day 'examining, directing, prescribing'.

The Cambridge Philosophical Society was founded in 1819 and Frederic Thackeray was one of its earliest Fellows, was elected to its Council in 1820, and served as Treasurer from 1825-1834. His first paper to the society, in November 1821, concerned some fossil remains found in the Isle of Ely. In 1827 he made some observations on the bones of the head of a swordfish, the sword of which he presented to the Society. The following year he read a paper 'On the case of Ann Carter, a young woman at Stapleford, said to be in a trance'. He continued until his death to play an active part in the administrative affairs of the society and refereed papers submitted for publication in the Transactions.

In his later years he was prominent in university offices. In 1835 and on several other occasions he was chosen a member of the Caput, the autocratic body any member of which could prevent a Grace from reaching the Senate. The Caput consisted (Winstanley, 1955) of the Vice-Chancellor, a doctor from each of the faculties of divinity, law and medicine, and one Regent and one non-Regent Master of Arts. Thackeray was also a member of 'The Family', the most exclusive of university dining clubs.

The letters to his mother of William Makepeace Thackeray (Ray, 1945), who came to Trinity College as an undergraduate in 1829, give us a young man's impressions of the older generations who received their young relative very warmly (Ray 1955). Frederic was his second cousin.

February 28th to March 5th 1829. a stupid evening at Mrs. Thackeray's [the widow of Thomas] -the old lady talked of nothing but fevers and deaths, though she said she loved the name of Thackeray.

March 6th-14th 1829. taking a moonlight walk I fell over head and ears in a ditch opposite Addingbrooke's [sic] Hospital. I might have been drowned with the greatest facility.

May 3rd 1829. I have just been drinking tea at Dr. Thackeray's where I met his mother and Aunt, 


\section{Arthur Rook}

the Vice-Provost of King's [Frederic's brother Martin George Thackeray was Provost] and Mr. Gunning-They were all declaring against the degeneracy of the present age or rather of the present youth . . . Mr. Gunning was rich in good stories.

May 11th-17th 1829. Doctor Thackeray detained me a long time-he is a very nice good humoured man, but intolerable prosy.

May 25th-29th 1829. I wrote nothing yesterday for my head would not allow me seeing that I had had leeches applied to it for the purpose of banishing that troublesome headache which had there taken up its quarters (of course its 'head' quarters). The application of the leeches has made me quite myself again today. It was by Dr. Thackeray's advice that they were put onhe will take no fee-what do you think me a Cannibal? quoth he, on my offer.

Frederic's sister Jane describes her brother as tall, fair and handsome, diffusing cheerfulness by his good and merry heart. He married in 1812 the widow of William Francis of Shepreth; she died in 1820. In 1821 he married Mary Elizabeth, daughter of Rev. Thomas Crick, Rector of Great Thurlow. Frederic remained in active practice until a few days before his death on 18 June 1852. He was buried at St. Botolph's Church. The shops were closed along the route of the funeral procession of two thousand mourners, who were joined at the gate of Emmanuel College by the resident Fellows. In 1855 the Rev. F. Thackeray, one of his sons, presented his father's portrait to the hospital where it now hangs in the Board Room (fig. 1).

\section{JOSEPH THACKERAY}

Joseph Thackeray, born on 27 March 1784, was the tenth son and sixteenth child of Thomas, the Cambridge surgeon. From Eton he entered King's College, Cambridge, in 1803 and was elected to a Fellowship in 1807. He took up medicine, under the erroneous impression that his father, then dead, would have wished him to do so, and studied for two years at Edinburgh, for one at Glasgow and for two in London, taking his M.B. at Cambridge in 1812 and proceeding M.D. in 1817.

According to his biographer: 'It is illustrative of the present state of the profession of physic, that although Dr Joseph Thackeray was eligible to the highest honours of the London College of Physicians, even under its own arbitrary bye-laws, he never connected himself with that learned body by becoming either a fellow or a licentiate'.

In 1812 Thackeray settled in Northampton but there was as yet no hospital there and he found that private practice alone offered him too little experience. He therefore moved to Bedford in 1814 at the suggestion of Dr. G. D. Yeats, physician to the Bedford Infirmary, who had resigned with the intention of practising in London. Thackeray was elected physician to the infirmary the same year. The following year he married Susannah, the daughter of Joseph Harden, a prosperous surgeon of Northampton.

The Bedford Infirmary (fig. 2), which was opened in August 1803, had been founded by Samuel Whitbread, the brewer, who died in 1796. The medical staff in 1814 consisted of one physician and two surgeons, Charles Short and John Pulley. Thackeray acquired a large practice but devoted much of his time and his personal fortune to the affairs of the infirmary. He set himself four main objectives all of which he ultimately achieved.

With the encouragement of his wife, who contributed $£ 100$ in 1823 , he persuaded the governors to establish a fund to support a permanent full-time chaplain. Two years later he himself contributed $£ 100$ to the fund and the Duke of Bedford, the Infirmary’s Grand Visitor, gave $£ 100$, a fee for Thackeray's professional services. By 


\section{The Thackerays and Medicine}

1831 the Chaplaincy fund had reached $£ 727.10$ s. $0 d$., and after a further appeal the first chaplain was appointed later in the same year.

In 1825 Thackeray made a passionate plea for the enlargement of the infirmary, and he, his wife and his mother-in-law made substantial contributions to the funds for this purpose. Additional accommodation for thirty patients was opened in 1828 .

In 1829 Thackeray drew the governors' attention to the fact that, although Addenbrooke's Hospital and the recently opened Northampton Infirmary were general hospitals, the Bedford Infirmary restricted its admissions to patients living in Bedfordshire. He said that he had on occasions broken the rules and admitted deserving cases from neighbouring counties but had always himself paid the maintenance charges of such patients. He felt that since many of the poor were compelled to leave their homes in search of work common interest 'required reciprocity of accommodation and relief'. In 1831 the governors passed a resolution 'That this Institution be hereby formally declared a General Infirmary open to the sick and necessitous poor of all Counties and all Nations. ....

In 1829 Thackeray urged upon the governors the need for a medical library. $\mathrm{He}$ presented about 400 of his own books, and so effectively persuaded local practitioners to give books that by the following year the library contained 1000 volumes. At this point a Medical Reading Society was founded; the society's books, after circulation, were to be placed in the hospital library, to which members would have free access.

Thackeray's final achievement, in which he was a pioneer, was the establishment of a pension fund for hospital employees.

Joseph Thackeray is described by his sister (Pryme and Bayne, 1879) as a tall slender man with a fresh complexion, who paid great attention to his dress; he usually wore a blue or green coat with gilt buttons, a buff waistcoat, pleated shirt frills of the finest cambric and top boots. In his last illness all the medical men of the town and neighbourhood took turns to watch by his bedside and assembled each evening for consultation, when they were joined by his brother Frederic from Cambridge.

He died on $5 \mathrm{July}, 1832$, one of the first victims of the cholera epidemic, and was granted a public funeral. The members of parliament for the town and the county posted down from London after a debate to act as pall-bearers. He was buried in St. Peter's Churchyard, Bedford: the inscription on his vault reads 'Fellow, King's College, Cambridge. Respected, beloved and lamented by all who knew him'. His portrait (fig. 3) by John Jackson, R.A., now hangs in the hall of the south wing of Bedford General Hospital. Shortly after the funeral, the Chairman and Committee of the Bedford Infirmary wrote to Frederic Thackeray offering to elect as their sole physician anyone he chose to recommend. Haviland proposed W. J. Bayne, on the grounds that he had passed the best examination for the M.D. he had ever known, but Bavne, who later practised in Southampton, refused the appointment.

When the governors met on 6 August to elect Thackeray's successor a letter was read to them from Dr. Thomas McGrath who attended Thackeray in his last illness. The letter conveyed Thackeray's dying wish 'that the Governors should inform all candidates for the appointment of Physician to the Charity that they were not to practise surgery in conjunction with physic, as he had seen the baneful consequence of such a practice at the Northampton Infirmary'. The governors discussed this letter 


\section{Arthur Rook}

at some length before proceeding to elect Dr. Witt as their physician. Thackeray was certainly looking to the future for it is doubtful whether any hospital physician in a small town could have supported himself had he not engaged in general practice.

FREDERIC THACKERAY, 1736-1782

Frederic, the fifth son of the Archdeacon, and a younger brother of Thomas, was born in 1736 at Haydon in Essex. He graduated M.B. of St. John's College, Cambridge, in 1764 and then settled at Windsor as a physician. His sister (Pryme and Bayne, 1879) claims that he was 'the favourite medical attendant of George III' but there is no record of his name in the index of Royal Households at Windsor or in the papers of the Lord Chamberlain's Office. His name does not appear in the private papers of George III (Mackworth-Young, 1969). However in the obituary of his son the Rev. Dr. George Thackeray, Provost of King's College, Cambridge, and Chaplain in Ordinary to George III from 1803, in the Gentleman's Magazine (21 October 1850, p. 664) Frederic is mentioned as a favourite physician of the king's. The evidence on this point is therefore conflicting but there is no doubt that Thackeray was a highly successful physician and the fact that his grandfather had been Chaplain to George III as Prince of Wales no doubt brought him many connections in court circles.

\section{THOMAS THACKERAY $1767-1853$}

Thomas, the eldest son of Thomas the Cambridge surgeon, was apprenticed to his father and was then a house pupil of John Hunter. He was Hunter's pupil at St. George's Hospital in 1784 and in 1786 was appointed House Surgeon. He was granted his diploma by the Company of Surgeons in 1786. He accompanied his brother Frederic to Paris with Astley Cooper and in 1788 he obtained an appointment as Assistant Surgeon in the Honorable East India Company (Madras Establishment). He returned to England in 1795 to marry Fanny Ward, a granddaughter of Russell Plumptre, Regius Professor of Physic at Cambridge. In 1796 he was appointed full Surgeon and was present at the capture of Seringapatam in 1799. He retired from the company's service in 1804. Soon after his wife's death in 1806 he returned to England permanently, bringing with him a considerable fortune. He appears to have retired from medical practice. His eldest son, Thomas James, was born in Madras in 1796. From Eton he went to St. John's College, Cambridge, where he qualified M.B. in 1820. 'He was indifferent to the emoluments of a profession' and never practised. He became a Captain in the Somerset Militia and published The Soldier's Manual of Rifle Firing, but he lived the greater part of each year in Paris.

\section{WILLIAM MAKEPEACE THACKERAY, 1770-1849}

William, the second son, and fifth child of Thomas, the Cambridge surgeon, was born on 15 April 1770. He was educated at Rugby School and matriculated from St. John's College, Cambridge, in 1788. He migrated to Trinity, where he took his M.B. in 1794 and proceeded M.D. in 1800. He settled in practice in Denbigh but later moved to Chester. In Chester he achieved great success in his practice as a physician and, like his brothers, he devoted himself to public service in a number of different spheres, education, hospital affairs and horticulture (fig. 4). The Blue Coat School in particular received his strong support. The Society of Arts awarded him its 


\section{The Thackerays and Medicine}

gold medal for planting trees. 'He lived to see a wide extent of the hilly country near Mold covered with trees raised from acorns of his own sowing' (Obituary, Chester Chronicle, 3 August 1849). He died in 1849 and was accorded a public funeral. His memorial inscription in Chester Cathedral praises him 'for his attention to their charitable institutions, his consideration for the sick and needy, his kindness to the street boy and orphan and his uniform readiness to rejoice with them that rejoice and weep with them that weep'.

He is said to have been an ardent Whig in his politics but the sentiments attributed to him by his sister (Pryme and Bayne, 1879) suggest a strong tinge of conservatism: 'I have heard him say that when he first commenced practice there were sixteen physicians within a radius of forty miles, all of them educated either at Cambridge or Oxford, and that when he should die there would not be one left. So much had the provincial profession fallen off in its dignity, owing to the infusion into it of less well-educated men'.

\section{DISCUSSION}

Medicine is traditionally a profession in which son has often followed father. There are indeed families in which the succession has continued without interruption through many generations-e.g. the Dimsdales in Hertfordshire (Munby, 1968). Most such families were general practitioners, and the goodwill of the practice, and often the house, formed part of the son's inheritance. In many provincial towns during the eighteenth and nineteenth centuries two or more generations served on the staff of the hospital but the hospital physician or surgeon in a small town was in fact in general practice and here too a commercial asset could be transferred to the son.

The Thackeray family illustrates the same principle in so far as Frederic took over the house and practice of his father Thomas. However the personal influence and example of Thomas must have been the main force which drew four of his sons into medicine. Indeed we know that Joseph entered medicine somewhat unwillingly merely because he believed that his father would have wished him to do so. Three of the four sons made important and strikingly similar contributions to the development of hospital medicine in their different towns, and although all were successful in practice it was for their promotion of hospital expansion and reform that they were chiefly remarkable.

It is interesting too that medicine failed to attract the next generation. Only Thomas James entered the profession and he soon gave up practice. The later Thackerays made their mark as academics, authors or administrators, diplomats or soldiers. Perhaps by the nineteenth century the profession seemed to have less to offer a family whose fortunes and social status were by now well established.

\section{ACKNOWLEDGEMENTS}

I am grateful to the Board of Governors of Addenbrooke's Hospital for giving me access to the Minute Books and other records. Mr. J. L. Stonebanks of Bedford has provided me with much information from the records of the Bedford General Hospital for which I am greatly indebted to him. I also acknowledge my appreciation of the assistance given me by Dr. Richard Hunter, and by the Librarians of Windsor Castle, the Royal College of Surgeons and Chester Public Library, and by Miss Larter, Librarian, Cambridge Philosophical Society. 


\section{Arthur Rook}

\section{REFERENCES}

[BARLOW, E.] 'Biographical Memoirs of the late Dr. Joseph Thackeray of Bedford', Trans. prov. med. surg. Ass., 1832-33, 1, 419.

COOPER, B. B., The Life of Sir Astley Cooper, London, Parker, 1843, vol. 1, p. 211.

Hunter, R. A., Macalpine, I, and Payne, L. M., 'The Country Register of Houses for the Reception of "Lunatics" 1798-1812', J. ment. Sci., 1956, 102, 856.

HUNTER, R. A., personal communication, 1968.

MACKWORTH-YOUNG, R., personal communication, 1969.

MelVILLE, L., William Mackepeace Thackeray, London, John Lane, 1910, vol. 1, p. 3.

Minute Books of the Board of Governors, Addenbrooke's Hospital, Cambridge.

Munby, L. M., in East Anglian Studies, Cambridge, Heffer, 1968, p. 117.

PRYMe, JANE T., and BAYNe, Alicia, Memorials of the Thackeray Family, privately printed, 1879.

RaY, G. N., The Letters and Private Papers of William Makepeace Thackeray, London, Oxford University Press, 1945, vol. 1.

Ray, G. N., Thackeray. The Uses of Adversity, London, Oxford University Press, 1955, p. 120.

Rook, A. J., 'Robert Glynn (1719-1800), physician at Cambridge', Med. Hist., 1969, 13, 251.

Rook, A. J., 'Haviland, Paget and Humphry. The Introduction of Clinical Teaching at Cambridge', in A. J. Rook (ed.), Cambridge and its Contribution to Medicine, London, Wellcome Institute of the History of Medicine, 1971.

ToYNBeE, P., and WhIBleY, L., (eds.), Correspondence of Thomas Gray, London, Oxford University Press, 1935, vol. 2, pp. 837 and 442.

Winstanley, D. A., Early Victorian Cambridge, 1955, pp. 162-4 and 238. 